УДК $336.76(477)$

Скоморович I. Г., д.е.н., професор

Львівський національний університет імені Івана Франка

\title{
МІСЦЕ ІНВЕСТИЦІЙНИХ ФОНДІВ НА РИНКУ ФІНАНСОВИХ ПОСЛУГ
}

У статті проаналізовано процедуру створення інститутів спільного інвестування в Україні, яка включає взаємодію 3 регулюючими органами та випуск цінних паперів для формування ресурсів корпоративних та пайових інвестиційних фондів. Розглянуто види інститутів спільного інвестування, що передбачені українським законодавством. Здійснено порівняння структури та динаміки активів інвестиційних фондів за останні п’ять років та вивчено їхній портфель цінних паперів. Досліджено резидентність та статус інвесторів інститутів спільного інвестування. Обгрунтовано необхідність активізації діяльності інвестиційних фондів в напрямку діджиталізації своїх послуг.

Ключові слова: інститут спільного інвестування, корпоративний інвестиційний фонд, пайовий інвестиційний фонд, активи, цінні папери, інвестори, діджиталізація.

Скоморович И. Г.

\section{МЕСТО ИНВЕСТИЦИОННЫХ ФОНДОВ НА РЫНКЕ ФИНАНСОВИХ УСЛУГ}

В статье проанализирована процедура создания институтов совместного инвестирования в Украине, которая включает взаимодействие с регулирующими органами и выпуск ценных бумаг для формирования ресурсов корпоративных и паевых инвестиционных фондов. Рассмотрены виды институтов совместного инвестирования, предусмотренны украинским законодательством. Проведено сравнение структуры и динамики активов инвестиционных фондов за последние пять лет и изучены их портфели ценных бумаг. Исследованы резидентность и статус инвесторов институтов совместного инвестирования. Обоснована необходимость активизации деятельности инвестиционных фондов в направлении диджитализации своих услуг.

Ключевые слова: институт совместного инвестирования, корпоративный инвестиционный фонд, паевой инвестиционный фонд, активы, ценные бумаги, инвесторы, диджитализация.

Skomorovych I.

\section{THE PLACE OF INVESTMENT FUNDS IN THE MARKET OF FINANCIAL SERVICES}

The article analyzes the procedure of collective investment schemes establishment in Ukraine, that includes interaction with regulating authorities and issuance of securities for the sake of developing the resources of corporate and share investment funds. Types of collective investment schemes, envisaged by the Ukrainian legislation, are considered. The structure and the dynamics of investment fund assets over the last five years are compared as well as their securities portfolio is studied. The residency and the status of investors of collective investment schemes is studied. The need for activating investment funds towards digitalization of their services is substantiated.

Key words: collective investment institution, corporate investment fund, share investment fund, assets, securities, investors, digitalization.

Постановка проблеми у загальному вигляді i iї зв'язок 3 важливими науковими та практичними завданнями. Одним із сегментів ринку фінансових послуг $\epsilon$ управління активами інститутів спільного інвестування (ICI), що полягає в акумулюванні коштів багатьох інвесторів, вкладенні їх в обрані активи та розподілі отриманих доходів серед учасників, які надали свої кошти для інвестування. ICI $\epsilon$ важливими суб’єктами інвестиційних відносин у ринковій економіці, адже завдяки своїй інвестиційній діяльності здатні задовольнити потреби реального та фінансового секторів економіки у додаткових грошових ресурсах. 3 іншого боку, залучаючи кошти фізичних 
та юридичних осіб, ICI дають їм змогу отримати додаткові доходи та мінімізувати ризик їхніх вкладень. Такий результат досягається завдяки професійному управлінню активами, що дозволяє у повній мірі застосовувати основний принцип інвестування диверсифікацію.

Аналіз останніх досліджень, у яких започатковано вирішення проблеми. Теоретичним питанням, що стосуються спільного інвестування, присвячені наукові роботи таких вітчизняних науковців, як Вергелюк Ю., Івахненко I., Криниця С., Мацук 3., Михайлик О., Науменко К., Шевченко А., Шпакович I., Щербина О., Яворська О. та ін. Необхідність наповнення національної економіки інвестиційними ресурсами потребує подальшого вивчення цього сегменту фінансового посередництва з акцентом на прикладних аспектах його функціонування в Україні.

Цілі статті. Мета дослідження полягає в тому, щоб визначити активність ICI на інвестиційному ринку України та виявити, який вплив справила діджиталізація фінансових послуг на їхню діяльність.

Виклад основного матеріалу дослідження 3 повним обгрунтуванням отриманих наукових результатів. В Україні ICI можуть створюватися у формі корпоративного або пайового інвестиційного фонду.

Корпоративним інвестиційним фондом (КІФ) є юридична особа, створена у формі акціонерного товариства, яка проводить виключно діяльність із спільного інвестування. Для створення КІФ випускають прості іменні акції, які існують лише в бездокументарній формі і які розміщують серед його засновників. Після цього відбувається реєстрація КІФ у органах державної реєстрації та внесення відомостей про фонд у Єдиний державний реєстр інститутів спільного інвестування, який веде Національна комісія 3 цінних паперів та фондового ринку (НКЦПФР). При цьому одним і з документів, який поряд із статутом засновники КІФ подають до НКЦПФР, є регламент фонду. Він визначає порядок, строки, умови та особливості діяльності такого інституційного інвестора. Складовою регламенту, зокрема, є інвестиційна декларація. Саме у ній визначено основні напрями та обмеження інвестиційної діяльності КІФ.

Обов'язковою умовою діяльності КІФ є укладення ним договору з компанією 3 управління активами (КУА). Це господарське товариство, створене у формі акціонерного товариства або товариства 3 обмеженою відповідальністю, для якого діяльність 3 управління активами ICI на підставі ліцензії, що видається НКЦПФР, є виключним видом діяльності, за яку воно отримує відповідну винагороду. Одна КУА одночасно може управляти активами кількох ICI.

Для того, щоб не допустити недобросовісних операцій з боку КУА, українським законодавством встановлено низку обмежень, що стосуються угод 3 активами, які перебувають в управлінні компанією. Крім того, з метою захисту інтересів ICI та їхніх учасників передбачено, що КУА несе майнову відповідальність за завдані збитки. Вони відшкодовуються з резервного фонду компанії, що формується за рахунок ії прибутку, а в разі недостатності резервного фонду - за рахунок іншого майна КУА.

Протягом року після моменту реєстрації КІФ у реєстрі ICI відбувається випуск акцій, що здійснюється з метою спільного інвестування. Реєстрацію їх та проспекту їхньої емісії в НКЦПФР проводить КУА, з якою КІФ має укладений договір про управління активами. Такі акції можуть бути лише іменними, а їхній випуск відбувається шляхом приватного або публічного розміщення компанією з управління активами або торговцем цінними паперами, з яким КУА уклала відповідний договір.

На відміну від КІФ, пайовий інвестиційний фонд (ПІФ) не є юридичною особою. Він $є$ «сукупністю активів, що належать учасникам такого фонду на праві спільної часткової власності» [2]. Ініціатива утворення ПІФ належить КУА, яка управляє цими активами та обліковує їх окремо від результатів своєї господарської діяльності. Для створення ПІФ КУА розробляє його регламент, реєструє його та сам фонд в НКЦПФР. ПІФ вважають створеним з моменту внесення інформації про нього до реєстру ICI. 
3 метою залучення коштів інвесторів КУА випускає та розміщує (публічно або приватно, самостійно або через торговця цінними паперами) інвестиційні сертифікати ПІФ, які, як і акції КІФ, є іменними та існують у бездокументарній формі. Інвестиційний сертифікат засвідчує право власності інвестора на частку в пайовому фонді та на отримання доходу у вигляді дивідендів.

При випуску цінних паперів ICI їхній емітент повинен зареєструвати проспект їхньої емісії в НКЦПФР. У випадку публічного розміщення акцій чи інвестиційних сертифікатів такий проспект підлягає оприлюдненню. Оплату цінних паперів ICI інвестори здійснюють грошима упродовж трьох робочих днів 3 моменту укладення договору про їхню купівлю. Законодавством України дозволена конвертація цінних паперів одного ICI в цінні папери іншого ICI, якщо активами обидвох ICI управляє одна КУА.

Особливістю створення ПІФ є неможливість передбачення попиту на інвестиційні сертифікати, адже протягом шістьох місяців 3 дня реєстрації їхнього випуску КУА повинна сформувати активи на суму принаймні 1250 мінімальних заробітних плат. 3 огляду на це, поки КУА не отримає від НКЦПФР повідомлення про те, що вимоги ПІФ відповідають мінімальному обсягу активів, вона може лише приймати від інвесторів заявки на придбання інвестиційних сертифікатів. Якщо нормативу не буде досягнено, їхній випуск НКЦПФР вважає таким, що не відбувся, а всі кошти, отримані пайовим фондом, КУА повертає інвесторам.

Отже, вітчизняні інститути спільного інвестування створюють у вигляді корпоративного або пайового інвестиційного фонду (табл. 1). Їхня діяльність неможлива без функціонування КУА, які здійснюють безпосереднє управління активами ICI. Дані, наведені в таблиці, показують, що в той час, коли кількість КУА за останні сім років зменшується, число ICI, які досягли мінімального обсягу активів залишається на одному рівні. Це свідчить про збільшення концентрації управління активами.

Таблиця 1

Кількість ICI та КУА в Україні протягом 2012-2018 рр., шт.*

\begin{tabular}{|l|c|c|c|c|c|c|c|}
\hline \multicolumn{1}{|c|}{ Показник } & 2012 & 2013 & 2014 & 2015 & 2016 & 2017 & 2018 \\
\hline Всього кількість ІСІ & 1544 & 1604 & 1569 & 1567 & 1625 & 1701 & 1783 \\
\hline $\begin{array}{l}\text { Всього кількість ІСІ, які досягли } \\
\text { мінімального обсягу активів }\end{array}$ & 1222 & 1250 & 1188 & 1147 & 1131 & 1160 & 1228 \\
\hline з них кількість КІФ & 256 & 262 & 237 & 254 & 288 & 333 & 413 \\
\hline \multicolumn{1}{|c|}{ кількість ПІФ } & 966 & 988 & 951 & 893 & 843 & 827 & 815 \\
\hline Кількість КУА & 353 & 347 & 336 & 313 & 295 & 284 & 296 \\
\hline Кількість ІСІ на одну КУА & 4,37 & 4,62 & 4,67 & 5,01 & 5,51 & 5,99 & 6,02 \\
\hline
\end{tabular}

* Побудовано автором за [1]

Крім КУА, іншою установою, що входить до інфраструктури обслуговування діяльності ICI в Україні, є зберігач активів ICI. Це установа, яка має ліцензію НКЦПФР на здійснення депозитарної діяльності зберігача цінних паперів і яка на підставі договору з КІФ або КУА, яка створила ПІФ, веде для них рахунки у цінних паперах. При цьому, якщо ICI здійснює публічне розміщення своїх цінних паперів, то зберігачем має бути банк $з$ кредитним рейтингом не ніжче, ніж інвестиційний клас, а якщо лише приватне, то будь-яка уповноважена юридична особа. Зберігач повинен слідкувати, чи відповідають здійснювані операції 3 цінними паперами регламенту ICI, проспекту емісії та законодавству.

Для проведення розрахунків КІФ відкриває рахунок у банку, а кошти кожного ПІФ обліковують на окремому банківському рахунку його КУА. У процесі своєї діяльності ICI також взаємодіють з оцінювачем майна, аудитором та Центральним депозитарієм цінних паперів.

Залежно від порядку провадження діяльності ICI є таких типів: 
- відкриті - ICI або КУА, яка ним управляє, беруть на себе зобов'язання здійснювати викуп емітованих ними цінних паперів у будь-який час на вимогу учасників ICI;

- інтервальні - ICI або КУА, яка ним управляє, беруть на себе зобов'язання здійснювати викуп емітованих ними цінних паперів протягом обумовленого в проспекті емісії строку на вимогу учасників ICI;

- закриті - ICI або КУА, яка ним управляє, не беруть на себе зобов'язання здійснювати викуп емітованих ними цінних паперів до моменту припинення ICI.

Залежно від терміну своєї діяльності ICI $\epsilon$ строковими та безстроковими. Стоковими $\epsilon$ ICI, що створюються на певний строк, визначений у їхньому регламенті. Зокрема, закриті ICI є лише строковими. Інші типи ICI можуть бути безстроковими, тобто створюватися на невизначений строк.

Крім того, ICI вважається диверсифікованим, якщо:

1) йому належить не більше 10 \% випуску цінних паперів одного емітента;

2) у випадку купівлі ним більше 5 \% випуску цінних паперів одного емітента вартість цього активу на момент його придбання не перевищуватиме $40 \%$ вартості чистих активів такого ICI;

3) не менше, ніж 70 \% загальної вартості його чистих активів становлять кошти, банківські метали, ощадні (депозитні) сертифікати, облігації підприємств та місцевих позик, державні цінні папери та цінні папери, які допущені до торгів на фондових біржах.

Ще одна класифікація ICI полягає у їхній спеціалізації та враховує напрямки інвестування ними коштів: фонди грошового ринку, фонди державних цінних паперів, фонди облігацій, фонди акцій, індексні фонди, фонди банківських металів. Подібний принцип поділу лежить в основі визначення кваліфікаційного виду ICI - ICI, який здійснює свої інвестиції лише в один із кваліфікаційних класів активів та кошти. Такими кваліфікаційними класами активів $є$ [2; 3]: об'єднаний клас цінних паперів (цінні папери та кошти), клас нерухомості (нерухомість, майнові права на нерухомість у процесі будівництва та кошти), клас рентних активів (майно, майнові права, які перебувають у цивільномц обороті), клас кредитних активів, клас біржових товарних активів та інші класи активів, визначені НКЦПФР.

Якщо ICI не підпадає під визначення диверсифікованого, спеціалізованого чи кваліфікаційного, то він $є$ недиверсифікованим. Якщо ж такий недиверсифікований ICI $\epsilon$ закритого типу і здійснює виключно приватне розміщення своїх цінних паперів, то він $\epsilon$ венчурним фондом (табл. 2).

Таблиця 2

Кількість ICI за видами та типами в Україні протягом 2012-2018 рр., шт.*

\begin{tabular}{|c|c|c|c|c|c|c|c|}
\hline Показник & 2012 & 2013 & 2014 & 2015 & 2016 & 2017 & 2018 \\
\hline $\begin{array}{l}\text { Всього кількість ICI, які досягли } \\
\text { мінімального обсягу активів }\end{array}$ & 1222 & 1250 & 1188 & 1147 & 1131 & 1160 & 1228 \\
\hline Кількість КІФ & 256 & 262 & 237 & 254 & 288 & 333 & 413 \\
\hline 3 них інтервальні диверсифіковані & 2 & 2 & 2 & 2 & 0 & 0 & 0 \\
\hline закриті недиверсифіковані & 110 & 90 & 75 & 63 & 55 & 53 & 51 \\
\hline закриті кваліфікаційні & 0 & 0 & 0 & 0 & 0 & 0 & 1 \\
\hline венчурні & 144 & 170 & 160 & 189 & 233 & 280 & 361 \\
\hline Кількість ПІФ & 966 & 988 & 951 & 893 & 843 & 827 & 815 \\
\hline З них відкриті диверсифіковані & \multirow{2}{*}{41} & \multirow{2}{*}{38} & 26 & 21 & 15 & 14 & 13 \\
\hline відкриті спеціалізовані & & & 4 & 5 & 5 & 5 & 6 \\
\hline інтервальні диверсифіковані & \multirow{2}{*}{38} & \multirow{2}{*}{35} & 29 & 22 & 21 & 20 & 19 \\
\hline інтервальні спеціалізовані & & & 1 & 2 & 3 & 3 & 3 \\
\hline закриті диверсифіковані & 13 & 11 & 10 & 9 & 4 & 4 & 4 \\
\hline закриті недиверсифіковані & 45 & 43 & 35 & 30 & 29 & 31 & 27 \\
\hline закриті спеціалізовані & 0 & 0 & 0 & 1 & 1 & 1 & 1 \\
\hline закриті кваліфікаційні & 0 & 0 & 0 & 0 & 0 & 1 & 1 \\
\hline венчурні & 829 & 861 & 846 & 803 & 765 & 748 & 742 \\
\hline
\end{tabular}

* Побудовано автором за [1] 
Наведений у табл. 2 кількісний розподіл ICI за видами та типами пояснюється кількома чинниками. По-перше, у законодавстві України передбачено, що відкриті ICI можуть бути лише диверсифікованими та спеціалізованими, а інтервальні - ще й кваліфікаційними. По-друге, велика кількість венчурних фондів пояснюється перш за все, слабким інтересом звичайних інвесторів до участі в ICI. Це змушує їхніх засновників надавати перевагу приватному розміщенню своїх цінних паперів. 3 іншого боку, невелика кількість привабливих для інвестування активів не дозволяє ICI виконувати вимоги щодо диверсифікації своїх активів.

Для того, щоб визначити динаміку розвитку ICI в Україні, необхідно не лише прослідкувати темпи приросту їхніх активів, але й порівняти їх 3 основними макроекономічними показниками (табл. 3).

Таблиця 3

Динаміка активів ICI в Україні протягом 2012-2018 рр.*

\begin{tabular}{|l|c|c|c|c|c|c|c|}
\hline \multicolumn{1}{|c|}{ Показник } & 2012 & 2013 & 2014 & 2015 & 2016 & 2017 & 2018 \\
\hline Активи ІСІ, млрд грн & 157,2 & 177,5 & 206,4 & 236,2 & 230,2 & 275,5 & 296,8 \\
\hline Темпи приросту активів ІСІ, \% & - & 12,9 & 16,3 & 14,4 & $-2,5$ & 19,7 & 7,7 \\
\hline Частка активів ICI у ВВП, \% & 11,2 & 12,1 & 13 & 11,9 & 9,7 & 9,2 & 8,3 \\
\hline $\begin{array}{l}\text { Відношення активів ICI до } \\
\text { активів банків, \% }\end{array}$ & 13,9 & 13,9 & 15,7 & 19,4 & 18,3 & 20,7 & 21,8 \\
\hline Рівень інфляції, \% & $-0,2$ & 0,5 & 24,9 & 43,3 & 12,4 & 13,7 & 9,8 \\
\hline
\end{tabular}

* Побудовано автором за $[1 ; 4]$

3 табл. 3 видно, що незважаючи на майже щорічне (за винятком 2016 р.) абсолютне зростання активів діючих ICI, темпи їхнього приросту були меншими, ніж рівень інфляції, а частка активів ICI у ВВП держави, починаючи 32015 p., постійно зменшувалася. Позитивним виглядає лише порівняння динаміки активів ICI з активами банківської системи України, які зростають ще меншими темпами.

ICI можуть формувати свої активи за рахунок коштів в національній та іноземних валютах, розміщених на поточних та вкладних рахунках в банках, банківських металів, об'єктів нерухомості, цінних паперів вітчизняних та іноземних емітентів, майнових та корпоративних прав, а також інших активів (табл. 4). Такі активи ICI оплачують за рахунок коштів спільного інвестування.

Таблиця 4

Структура активів ICI в Україні у 2014-2018 pр., \%*

\begin{tabular}{|c|c|c|c|c|c|}
\hline \multicolumn{2}{|c|}{ Показник } & Відкриті ICI & Інтервальні ICI & $\begin{array}{c}\text { Закриті ICI (крім } \\
\text { венчурних) }\end{array}$ & Венчурні ICI \\
\hline \multirow{5}{*}{ Цінні папери } & 2014 & 65,33 & 74,81 & 53,07 & 27,31 \\
\hline & 2015 & 64,98 & 70,55 & 31,82 & 20,2 \\
\hline & 2016 & 67,26 & 74,81 & 27,3 & 21,49 \\
\hline & 2017 & 67 & 81,3 & 24,9 & 15,9 \\
\hline & 2018 & 69,9 & 86,7 & 12,2 & 10,7 \\
\hline \multirow{5}{*}{ Кошти } & 2014 & 23,08 & 14,21 & 6,44 & 1,5 \\
\hline & 2015 & 23,58 & 9,9 & 11,63 & 1,44 \\
\hline & 2016 & 24,83 & 14,43 & 15,6 & 1,39 \\
\hline & 2017 & 26 & 13 & 15,2 & 1,3 \\
\hline & 2018 & 24,9 & 9 & 7,1 & 1,2 \\
\hline \multirow{5}{*}{ Нерухомість } & 2014 & - & - & 0,2 & 2,22 \\
\hline & 2015 & - & - & 0,17 & 2,71 \\
\hline & 2016 & - & - & 0,2 & 2,87 \\
\hline & 2017 & - & - & 0,2 & 2,7 \\
\hline & 2018 & - & - & 0,2 & 3,3 \\
\hline \multirow{5}{*}{$\begin{array}{c}\text { Банківські } \\
\text { метали }\end{array}$} & 2014 & 1,74 & 0,76 & - & 0,01 \\
\hline & 2015 & 2,37 & - & 0,03 & - \\
\hline & 2016 & 0,92 & - & 0,04 & - \\
\hline & 2017 & 1 & - & 0,02 & - \\
\hline & 2018 & 1,2 & - & 0,02 & - \\
\hline
\end{tabular}


продовження таблиці 4

\begin{tabular}{|c|c|c|c|c|c|}
\hline 1 & 2 & 3 & 4 & 5 & 6 \\
\hline \multirow{5}{*}{ Інші активи } & 2014 & 9,85 & 10,21 & 40,29 & 68,96 \\
\cline { 2 - 6 } & 2015 & 9,06 & 19,55 & 56,34 & 75,65 \\
\cline { 2 - 6 } & 2016 & 6,99 & 10,76 & 56,9 & 74,26 \\
\cline { 2 - 6 } & 2017 & 6 & 5,7 & 59,6 & 80,1 \\
\cline { 2 - 6 } & 2018 & 4 & 4,3 & 80,6 & 84,8 \\
\hline
\end{tabular}

* Побудовано автором за [1]

Статистичні дані свідчать, що склад активів ICI дещо відрізняється залежно від його типу. Зокрема, у той час як відкриті та інтервальні ICI змушені більшість своїх активів утримувати в більш ліквідних цінних паперах та залишках на рахунках в банках, закриті ICI можуть собі дозволити шукати прибутковіші напрямки вкладень. Крім того, не дивлячись на те, що для венчурних ICI встановлені дещо ліберальніші вимоги до складу активів, в них левову частку становлять інші активи, які включають переважно дебіторську заборгованість (у тому числі позики) та корпоративні права.

Активи ICI не можуть включати:

1) цінні папери інших ICI;

2) приватизаційні цінні папери;

3) договори про участь у фонді фінансування будівництва;

4) цінні папери, випущені КУА, зберігачем активів ICI, Центральним депозитарієм цінних паперів, оцінювачем майна та аудитором ICI;

5) цінні папери, випущені пов'язаними особами КУА, зберігача активів ICI, Центрального депозитарію цінних паперів, оцінювача майна та аудитора ICI;

6) цінні папери іноземних емітентів, не допущені до торгів на жодній з визначених НКЦПФР іноземних фондових бірж;

7) іпотечні облігації, облігації підприємств та місцевих позик, кредитний рейтинг яких не відповідає інвестиційному рівню, на суму більше, ніж 20 \% вартості активів ICI;

8) кошти і банківські метали на поточних і вкладних рахунках у банках, кредитний рейтинг яких не відповідає інвестиційному рівню, на суму більше, ніж 20 \% вартості активів ICI; ICI;

9) векселі та ощадні (депозитні) сертифікати на більше, ніж 10 \% вартості активів

10) товаророзпорядчі цінні папери, заставні;

11) сертифікати фондів операцій з нерухомістю.

На венчурні фонди розповсюджується обмеження, встановлені у перших чотирьох перелічених пунктах. Крім того, венчурні фонди можуть надавати позики, проте лише юридичній особі, не менше 10 \% статутного капіталу якої належить такому ICI.

3 огляду на те, що головне призначення ICI полягає у спільному інвестуванні коштів у фондові активи, найбільший інтерес викликає портфель цінних паперів (табл. 5), сформований українськими інвестиційними фондами.

Таблиця 5

Портфель цінних паперів ICI в Україні у 2014-2018 pp.*

\begin{tabular}{|c|c|c|c|c|c|c|c|c|c|c|}
\hline \multirow[b]{2}{*}{ Вид цінного паперу } & \multicolumn{2}{|c|}{2014} & \multicolumn{2}{|c|}{2015} & \multicolumn{2}{|c|}{2016} & \multicolumn{2}{|c|}{2017} & \multicolumn{2}{|c|}{2018} \\
\hline & 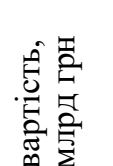 & 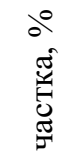 & 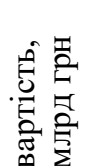 & 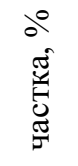 & 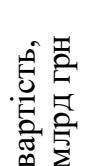 & 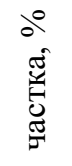 & 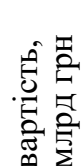 & 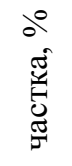 & 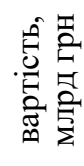 & 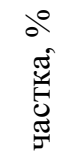 \\
\hline Акції & 34,4 & 58,2 & 26,2 & 53,8 & 28,2 & 56,3 & 21,5 & 50,4 & 12,8 & 39,6 \\
\hline Векселі & 15,9 & 26,9 & 13,2 & 27,1 & 12,7 & 25,3 & 11,7 & 27,4 & 9,2 & 28,6 \\
\hline Деривативи & 0,08 & 0,1 & 0,07 & 0,1 & 0,24 & 0,5 & 0,86 & 2,0 & 1,47 & 4,6 \\
\hline Заставні & 0,02 & 0,03 & 0,02 & 0,04 & 0,012 & 0,02 & 0,01 & 0,02 & 0,00 & 0,0 \\
\hline Облігації державні & 0,33 & 0,6 & 0,29 & 0,6 & 0,43 & 0,9 & 0,5 & 1,2 & 0,76 & 2,3 \\
\hline Облігації місцеві & 0,0008 & 0,0 & 0 & 0 & 0 & 0 & 0 & 0 & 0 & 0 \\
\hline Облігації підприємств & 8,38 & 14,2 & 8,9 & 18,3 & 8,5 & 17 & 8,11 & 19,0 & 8 & 24,9 \\
\hline Всього & 59,13 & 100 & 48,71 & 100 & 50 & 100 & 42,7 & 100 & 32,2 & 100 \\
\hline
\end{tabular}

* Побудовано автором за [1] 
Аналіз табл. 5 свідчить, що портфель цінних паперів ICI в Україні в цілому відображає головні тенденції, які характерні для розвитку вітчизняного фондового ринку протягом останніх п'яти років. Зокрема, загальне зменшення вартості портфеля цінних паперів в основному відбулося за рахунок зменшення вкладень в акції (в абсолютному вираженні - на 21,64 млрд грн), що призвело до того, що їхня частка впала на 18,6 \%. Таке радикальне зменшення частки акцій у портфелі насамперед викликане посиленням вимог НКЦПФР до їхній емітентів та усуненням з ринку «сміттєвих» цінних паперів. Заборона торгувати векселями на фондових біржах спричинила поступове зменшення зацікавленості ICI в такому виді цінного паперу (в абсолютному вираженні - на 6,7 млрд грн). Значне зростання частки облігацій підприємств у портфелі цінних паперів (на 10,7 \%) викликане загальним зменшенням цього портфеля, адже в абсолютному вираженні вартість корпоративних облігацій навіть зменшилась (на 0,38 млрд грн). Цікаво, що приблизно на таку ж суму зросли вкладення ICI в державні облігації. При цьому найбільший приріст вартості ОВДП в портфелі цінних паперів спостерігався у 2018 р., що також цілком відповідає тенденціям, що характерні для фондових операцій в Україні.

Учасниками ICI, тобто власниками цінних паперів, випущених ICI або КУА, які ними управляють, можуть бути юридичні та фізичні особи, резиденти та нерезиденти. Не можуть бути учасниками ICI держава, територіальні громади, а також юридичні особи, в яких частка державної або комунальної власності перевищує $25 \%$. Фізичні особи можуть стати учасниками венчурного фонду, якщо вони купують цінні папери такого ICI на суму не менше, ніж 1500 мінімальних місячних заробітних плат станом на 1 січня 2014 р., а кваліфікаційного ICI, якщо вартість придбаного пакету цінних паперів не менше 100 мінімальних місячних заробітних плат станом на 1 січня 2014 р. (табл. 6).

Таблиця 6

Кількість та частка інвесторів в ICI в Україні станом на кінець 2018 р.*

\begin{tabular}{|c|c|c|c|c|c|c|c|c|}
\hline \multirow{3}{*}{ Фонди } & \multicolumn{4}{|c|}{ Резиденти } & \multicolumn{4}{|c|}{ Нерезиденти } \\
\hline & \multicolumn{2}{|c|}{ Юридичні особи } & \multicolumn{2}{|c|}{ Фізичні особи } & \multicolumn{2}{|c|}{ Юридичні особи } & \multicolumn{2}{|c|}{ Фізичні особи } \\
\hline & к-сть & частка & к-сть & частка & к-сть & частка & к-сть & частка \\
\hline Відкриті & 19 & 9,3 & 1622 & 77,8 & 8 & 12,7 & 1 & 0,2 \\
\hline Інтервальні & 18 & 12,8 & 249822 & 85,3 & 1 & 1,9 & 18 & 0 \\
\hline $\begin{array}{l}\text { Закриті } \\
\text { (крім } \\
\text { венчурних), }\end{array}$ & 356 & 15,5 & 3794 & 76,7 & 24 & 7,7 & 8 & 0,1 \\
\hline $\begin{array}{l}\text { публ. } \\
\text { емісією }\end{array}$ & 164 & 39,9 & 3735 & 13,7 & 15 & 46,3 & 8 & 0,1 \\
\hline $\begin{array}{l}\text { прив. } \\
\text { емісією }\end{array}$ & 192 & 10,8 & 59 & 88,9 & 9 & 0,3 & 0 & 0 \\
\hline Венчурні & 2890 & 65,6 & 572 & 10,9 & 386 & 23,3 & 9 & 0,2 \\
\hline Всього & 3283 & - & 255810 & - & 419 & - & 36 & - \\
\hline
\end{tabular}

* Побудовано автором за [1]

Не дивлячись на переважаючу чисельну більшість вітчизняних інвесторівфізичних осіб, кількість яких становить 98,56 \% від загальної кількості учасників ICI, статистика Української асоціації інвестиційного бізнесу свідчить, що найактивнішими інвесторами є юридичні особи-резиденти. Проте необхідно зауважити, що їхня частка у вкладеннях в ICI з 2012 р. до 2018 р. зменшилася з 81 до 62,3 \% чистих активів усіх ICI [1].

Одним 3 можливих напрямків розвитку діяльності ICI в Україні повинно стати переведення їхньої взаємодії зі своїми клієнтами у цифровий формат, тим більше, що Закон України «Про інститути спільного інвестування» вимагає від КУА розміщувати 
інформацію про функціонування корпоративних та пайових фондів, якими вони управляють, на своїх веб-сайтах. Крім того, дані про видані КУА ліцензії на здійснення професійної діяльності з управління активами є на сайті НКЦПФР та Української асоціації інвестиційного бізнесу (УАІБ), яка є саморегулівною організацією, що об'єднує професійних учасників фондового ринку.

Станом на червень 2019 р. на сайті УАІБ є інформація про 295 КУА, з яких ми розглянули 148 веб-сайтів, що становить більше 50 \%. Огляд засвідчив, що переважна більшість КУА відносяться до їхнього наповнення формально, адже оприлюднюють виключно ті відомості, які вимагає законодавство: дозвільні документи, фінансову звітність, перелік осіб, які обслуговують фонди, тощо. Близько 20 сайтів КУА містять загальну інформацію про послуги, які вони надають, ознайомлюють 3 діяльністю ICI, наводять аргументи на користь спільного інвестування та 5 КУА вказують на сайті вартість чистих активів фондів та ії динаміку. Лише 8 КУА розміщують на своїх сайтах послідовність кроків, які повинен зробити клієнт для того, щоб стати учасником фонду. При цьому всі наголошують на тому, що клієнти повинні для цього відвідати офіс КУА, один з них пропонує надсилати необхідні документи поштою і ще один робить можливим співпрацю 3 клієнтом через використання і накладення електронного цифрового підпису на договори купівлі-продажу цінних паперів ICI.

Висновки. Незважаючи на велику кількість ICI в Україні, їхня активність на ринку фінансових послуг явно недостатня для забезпечення інвестиційними ресурсами національної економіки. Головними перешкодами для їхньої діяльності $\epsilon$ невелика кількість інструментів вітчизняного фондового ринку, низький рівень заощаджень домогосподарств та незначний рівень проникнення діджиталізації у взаємовідносини між учасниками і управляючими ICI.

\section{Список бібліографічного опису:}

1. Квартальні та річні огляди ринку управління активами/Українська Асоціація Інвестиційного Бізнесу. URL: http://www.uaib.com.ua/analituaib/publ_ici_quart.html.

2. Про інститути спільного інвестування: Закон України від 5 лип. 2012 р. № 5080-VI/Верховна Рада України. URL: http://zakon.rada.gov.ua/laws/show/5080-17.

3. Положення про склад та структуру активів інституту спільного інвестування: Рішення НКЦПФР від 10 верес. 2013

p. № 1753/Верховна Рада України. URL: http://zakon.rada.gov.ua/laws/show/z1689-13.

4. Статистична інформація / Державна служба статистики. URL: http://www.ukrstat.gov.ua.

\section{References:}

1. Kvartalni ta richni oglyady rynku upravlinnya aktyvamy [Quarterly \& Annual Asset Management Industry Rewiews]. Ukrayinska Asotsiatsiya Investytsiynogo Biznesu. Retrieved from http://www.uaib.com.ua/analituaib/publ_ici_quart.html. [in Ukrainian].

2. Zakon Ukrayiny "Pro Instytuty spilnogo investuvannya" pryiniatyi 05 lyp. 2012 roku № 5080-VI [Law of Ukraine "On Collective Investment Institutions" from July 5, 2012, № 5080-VI]. Verhovna Rada Ukrayiny. Retrieved from http://zakon.rada.gov.ua/laws/show/5080-17. [in Ukrainian].

3. Polozhennya pro sklad ta strukturu aktyviv instytutu spilnogo investuvannya, uhvalene Riszenniam NKCPFR 10 veres. 2013 roku № 1753. [Regulation “On Composition and Structure of Assets of Collective Investment Institutions”, approved by the Resolution of NSSMC from September 10, 2013, № 1753]: Verhovna Rada Ukrayiny. Retrieved from http://zakon.rada.gov.ua/laws/show/z1689-13. [in Ukrainian].

4. Statystychna informatsiya [Statistical information]. Derzhavna sluzhba statystyky Ukrayiny. Retrieved from http://www.ukrstat.gov.ua. [in Ukrainian]. 